\title{
Armed groups and mining
}

\section{Laura Bolton}

IDS

7 September 2021

\section{Question}

What does the literature say about the relationship between armed groups and mining/extractives, and past approaches to limiting their influence? The main area of interest is the Great Lakes region.

\section{Contents}

1. Summary

2. Linkage between mining and armed groups in DRC

3. Policy and regulation

4. Further links

The K4D helpdesk service provides brief summaries of current research, evidence, and lessons learned. Helpdesk reports are not rigorous or systematic reviews; they are intended to provide an introduction to the most important evidence related to a research question. They draw on a rapid deskbased review of published literature and consultation with subject specialists.

Helpdesk reports are commissioned by the UK Foreign, Commonwealth, and Development Office and other Government departments, but the views and opinions expressed do not necessarily reflect those of FCDO, the UK Government, K4D or any other contributing organisation. For further information, please contact helpdesk@k4d.info. 


\section{Summary}

The relationship between armed groups and mining is complex. Reports of armed interference in mining are provided by the United Nations (UN) Group of Experts on the Democratic Republic of Congo (DRC) and reported in the literature, including which groups have been found to operate in which areas. Academic analysis finds the presence of industrial mining companies reinforces the power of politico-military entrepreneurs.

This rapid review found a relatively large body of literature on the issue of armed groups and mining. Articles are a mix of academic literature and agency report prioritised based on relevance to the question, date (more recent), and location (Great Lakes, specifically DRC). They are recorded in annotated bibliography format. Further references which were not prioritised but provide useful information. The complexity of the issue requires broader investigation than is possible within the scope of a K4D helpdesk.

Key findings:

\section{Linkage between mining and armed groups:}

- A report on 182 mines in Eastern DRC prone to interference estimates their total production value to be USD 35.5 million (de Brier, 2021). A report sampling 300 mines finds armed groups present at $16 \%$ and the Congolese army present at $36 \%$ (Malango, 2016). Direct interference was found in $84 \%$ of the mines that had armed group or military presence. Interference in the mining sector often involves threats of violence or destruction of property if money is not paid to the armed groups for protection. Illegal taxation activities include charging a fee upon entrance and exit to a mine, charging per bag of minerals taken out of the mine, and charging a monthly fee to the mine owners.

- Initiatives for responsible supply chains include the International Tin Association Tin Supply Chain Initiative Programme for Responsible Mineral Supply Chains; and a validation system carried out by teams of government officials and international partners. Reports of success of these schemes are mixed and it is possible that sites attracted to validation schemes already have low levels of violence.

\section{Policy and regulation:}

- There is high chance of corruption in certification and validation processes. US corporations have reported difficulty in determining the country of origin of materials, particularly those with dispersed supply chains. Standards implementation in the mid- to downstream depend on upstream quality enforcement where institutional capacity is lacking. Resources for ensuring mineral bags are sealed at the mine level are low. Auditing costs are high for artisanal mining regulation.

- Strategic Dialogue on Sustainable Raw Materials for Europe suggest using a minimum standards criteria, which can be raised incrementally as operators gradually improve their practice (Eslave, 2018). Local cultural and social dynamics need to be considered for adequate incentive certification scheme design.

- It is noted that armed groups have other sources of funding outside of direct involvement in artisanal mining, such as road blocking and looting. International policies are found to focus on conflict-free sourcing rather than peace promotion. Unintended negative 
impacts of international policies are discussed in the literature. Responsible sourcing has been found to reduce revenues for miners because of the costs of implementing regulations. Loss of revenue has been linked to a marked increase in infant deaths as a result of mothers reduced consumption of infant healthcare goods.

- EU regulations are criticised for targeting importers as this means companies dealing with the finished product will not be accountable (Addaney \& Lubaale, 2021).

Literature mentioning a gender dimension in this topic was not relevant enough to the question for inclusion in the main body of this report. Two references in the further links section discuss gender. No mention of disability was found within the scope of this report.

\section{Linkage between mining and armed groups in DRC}

\section{Mapping artisanal mining areas and mineral supply chains in eastern DR Congo. Impact of armed interference \& responsible sourcing}

Matthysen, K., Spittaels, S., \& Schouten, P. (2019). The International Peace Information Service (IPIS).

https://ipisresearch.be/wp-content/uploads/2020/10/1904-IOM-mapping-eastern-DRC.pdf

This report provides figures on the levels of armed interference in different provinces in eastern DRC. It is based on ten years of research. Armed interference is most frequent in North Kivu, South Kivu, and Ituri. Armed interference was reported at a third of the visited mines or more. Groups interfering in North Kivu include the Mai Simba, the two Nduma Defense of Congo (NDC) factions, and the Nyatura militia. South Kivu is mainly impacted by Raia Mutomboki and Mai Yakutumba. Ituri face interference from the Forces de Résistance Patriotique d'Ituri (FRPI) and Mai rebels. Overall across eastern DRC, units of the Congolese army (FARDC) are the most often identified.

Data shows that "artisanal mining only constitutes one among many sources of financing for conflict actors in eastern DRC, such as roadblocks and the taxation of other kinds of natural resources. Research on roadblocks demonstrates that armed actors do not need to have direct control over mining sites to benefit from the artisanal mining sector. While armed actors, and especially army units, might not be physically present at some mines in militarised mining areas, IPIS notes a consistent pattern whereby the army instead consistently erects roadblocks some distance away from these mining sites. The Congolese army is present at almost half of the total number of roadblocks that were mapped, and is responsible for nearly half of all the instances in which minerals were taxed" ( $p 7)$.

IPIS data is unable to prove that armed conflicts are related to interference in the mining sector. Rather, armed interference often manifests as illegal protection rackets ${ }^{1}$ with armed confrontations taking place, elsewhere. The illegal protection rackets contribute to overall insecurity in the region and makes it difficult to conduct ethically responsible business.

\footnotetext{
1 'a criminal system of taking money from people in exchange for agreeing not to hurt them or damage their property' https://dictionary.cambridge.org/dictionary/english/protection-racket
} 
In Eastern Congo there are mines covered by the iTSCi (International Tin Association Tin Supply Chain Initiative) Programme for Responsible Mineral Supply Chains. And 'green validated mines' which are visited by a validation team including government, state agencies and international partners which assess the security situation and socio-economic risks. IPIS record data on armed interference in iTSCi mines and validated mines to compare with interference in non-iTSCi mines and non-validated mines finding that mines with responsible sourcing initiatives have lower levels of armed interference. ${ }^{2}$ However, it may not be the case that the programmes create better security, but rather that sites with low-level armed involvement are attracted to the validation or iTSCi programmes. Responsible sourcing is carried out in most accessible sites and armed interference continues undisturbed in more remote areas.

Interviews with local stakeholders finds a perception that responsible sourcing has decreased their revenues. "Miners claimed that landowners, cooperatives and state officials have raised their levies. Consequently, people complained that responsible sourcing has mostly benefited local elites" (p9).

Challenges to responsible supply chains include limited state agents being unable to ensure mineral bags are sealed at the mine level with traceability tags. Corruption has been found present in the tagging process including levying of illegal taxes. In some areas contamination of supply chains are linked to armed groups. Increased responsible sourcing also seems to be particularly beneficial to local elites.

There is a risk that responsible sourcing does not address the drivers of armed interference. The report concludes that sustainable sourcing interventions have limited impact on local development.

\section{Luddites in the Congo? Analyzing violent responses to the expansion of industrial mining amidst militarization}

Verweijen, J. (2017). City, 21(3-4), 466-482.

https://www.tandfonline.com/doi/abs/10.1080/13604813.2017.1331567?journalCode=ccit20

This paper analyses the interplay between armed mobilisation against industrial mining in the Fizi-Kabambare region of DRC. "It argues that the presence and practices of industrial mining companies reinforce the overall power position of politico-military entrepreneurs. This occurs both directly, by efforts to co-opt them, and indirectly, by fueling dynamics of conflict, insecurity and protection that crucially underpin these entrepreneurs' dominance. At the same time, due to the eastern Congo's convoluted political opportunity structure for contentious action, politicomilitary entrepreneurs enlarge the scope for social mobilization against industrial mining. They offer a potential counterweight to repressive authorities and provide collective action frames that inspire contentious politics." (p466).

\footnotetext{
2 iTSCi mines represented $38 \%$ of sites visited and validated mines, $26 \%$.
} 
The study contexts align to some extent with a framework proposed by Holden \& Jacobsen $(2017)^{3}$ which links large-scale mining (LSM) to violent conflict through 1) protection rents, 2) stifling opposition through militarisation, and 3) grievances creating support for rebellion. However, interplay was found to be more complex than the framework. For example "While LSM companies like Banro indeed provide armed actors with resources by paying protection rents, these payments are part of a wider and more fine-grained politics of co-opting politico-military entrepreneurs. Such cooptation may also assume the form of providing favors to civilian political actors that are in close contact with armed groups" (p478).

3 Holden, William, and R. Daniel Jacobson. 2007. "Mining Amid Armed Conflict: Nonferrous Metals Mining in the Philippines." The Canadian Geographer/Le Ge'ographe canadien 51 (4): 475-500. 


\section{Conflict analysis and stakeholder mapping in South Kivu and Ituri}

de Brier, G. (2021). IPIS.

https://ipisresearch.be/publication/madini-conflict-analysis-and-stakeholder-mapping-in-themining-regions-of-south-kivu-and-ituri/

This report is a context analysis for the Madini project which aims to improve security and stability around mining sites in East DRC, and reduce smuggling in the Great Lakes region. The project targets 182 sites selected as particularly prone to interference from Forces armées de la république démocratique du Congo (FARDC). The production value at the 182 sites is estimated to be USD 35.5 million. FARDC are present in $95 \%$ of the sites in South Kivu, and $66 \%$ in Ituri. Presence is often accompanied by interference including tax on people. There is also non-state armed group involvement. There are estimated to be 125 non-state armed groups in North and South Kivu alone giving an indicator to the complexity of conflicts in East Congo.

One of the problems is that Civil Servants in the mining authority are not being paid their salary so predate on the profits of artisanal miners. Aside from mining, agriculture and civil service, the only other means of subsistence is to join an armed-group and get involved in taxing and looting. "For the miners, armed groups and undisciplined soldiers are the 'triggers' of 'immediate' conflicts because they impose themselves as mediators in disputes between stakeholders in the mine, and this 'mediation' becomes a new source of income" ( $p 17)$. Furthermore, "the presence of natural resources, in a context where the state is failing and relies on an unpaid army to assert its authority, leads to a militarisation of society and the economy, where poverty and the tradition of conflict drive new recruits into armed groups." (p20).

Specific conflicts in the Shabunda region include opposition to the extension of a national park, rivalry over site ownership, tension between miners and processing entities, and failure of the trading centre to stop contamination of mineral supply chains.

Causes of conflict in the Fizi region include opposition of the local population to a mining company, rivalry between cooperatives, and dispute by local chiefs over chiefdom.

Conflict in the mining sector in Djuga is caused by the presence of the CODECO 4 group which the government are trying to demobilise and neutralise. The CODECO maintain tension between Lendu and Hama with regards to mine ownership. Another source of conflict in the region is over the decision by a mining cooperative to establish a Chinese mining company for semi-industrial exploitation igniting conflict between two groups ${ }^{5}$ which persists despite the exit of the Chinese company.

Mambasa and Kalehe have less conflict of the five regions visited.

The report concludes with recommendations specific to national authorities, for the FARDC, for the provincial authorities of South Kivu and Ituru, for the Madini consortium, for foreign-owned industrial companies, for Congolese-owned industrial companies, for cooperatives, and for civil society organisations.

\footnotetext{
${ }^{4}$ Association of various military groups in the DRC

5 Taratibu and Kepka
} 


\section{Armed groups and mineral extraction in the DRC}

Malango, W. (2016). World Policy, (March 8th, 2016) http://worldpolicy.org/2016/03/08/armedgroups-and-mineral-extraction-in-the-drc/

This study, undertaken with the DRC Entrepreneurship and Development Initiative, found "there is not enough evidence to prove that armed groups operating in the eastern DRC rely solely on illegal exploitation of minerals to carry out their operations. Therefore, more research should be done to assess the factors that have helped these armed groups stay afloat". . Authors suggest developing an anti-armed groups strategy for the region. Mining sector strategies including embargoes, due diligence, traceability, certification, and formalization have not deterred armed groups from violating human rights and disrupting state authorities.

The study categorises armed group involvement as 'presence' as one category and the further whether this presence involved interference or not. Armed groups were involved by presence in $16 \%$ of the 300 mines visited and the Congolese army in $36 \%$. Armed groups and the national army were involved more directly in interference in $84 \%$ of the mines they were present in. Of the 131 mines registering interference, illegal taxation by armed groups was occurring in 35 of them, buying minerals in 2, digging for minerals in 1 , and forced labour in 4 . Interference by the Congolese army was occurring through illegal taxation in 61 mines, they were digging for minerals in 12, forced labour in 9 and buying minerals in 7 .

Illegal taxation activities included charging anyone leaving or entering the mine a small fee, charging a small fee per bag of minerals taken out of the mine, and charging a monthly fee to the mine owners.

The author concludes that it is difficult to link armed groups ability to perpetrate violence and disrupt the state with mineral activities as the Congolese army interference was found to be greater.

\section{Taxation, Stateness and Armed Groups: Public Authority and Resource Extraction in Eastern Congo}

Hoffmann, K., Vlassenroot, K., \& Marchais, G. (2016). Development and Change, 47(6), 1434-1456. https://biblio.ugent.be/publication/8149699/file/8149704.pdf

This paper describes the taxation practices of armed groups in Eastern DRC and argues that "their modes of taxation are based on long-standing registers of authority and practices of rule that originate in the colonial era" ( $\mathrm{p} 1434)$. Taxation ranges from plunder to protection rackets, to the material reciprocation of the recognition of rights.

Case studies show how taxation in Kalehe and Walikale revolve around taxes for protection arrangements. And that taxation of contemporary armed groups are often framed within "existing registers of authority and modes of rule, notably by re-activating ethnoterritorial ontologies of

\footnotetext{
${ }^{6}$ Page number unavailable
} 
local political space, community and citizenship to legitimize extractive taxation practices" (p1452).

\title{
Artisanal or industrial conflict minerals? Evidence from Eastern Congo
}

Stoop, N., Verpoorten, M., \& Van der Windt, P. (2019). World Development, 122, 660-674.

https://www.sciencedirect.com/science/article/abs/pii/S0305750X19301780

This research looks at the differences between artisanal and large-scale mining (LSM) links with local conflict. Rising mineral prices increase battles over artisanal mines with competition between armed groups, but less so for LSM. Expansion of industrial mining seems to decrease battles as companies secure their concessions. Expansion can trigger riots when it crowds out artisanal mining.

\section{United Nations Group of Experts on the DRC}

\author{
Final report of the Group of Experts on the Democratic Republic of the Congo \\ [S/2021/560] \\ United Nations Security Council, June 2021 \\ https://www.ecoi.net/en/file/local/2053905/S_2021_560_E.pdf
}

This is the most recent of the Group of Experts (and UN Security Council) reports on the DRC. It provides highly detailed information on armed group activity in the mining sector in North Kivu, Ituri, and South Kivu.

The Group documents illegal presence of particular groups identifying specific areas and mines. It reports on which groups benefitted from mining and taxation and in which areas. It records where different groups have fought and taken control of certain mines. It reports gold trading from certain locations with certain countries. For example "Gold production from Walikale was traded in Rwanda, via Bukavu, and in Uganda" (paragraph 54, p16). There are also reports of an armed group benefitting from taxation in gold mining sites in two areas where gold was exported to Hong Kong.

Reports of clashes between specific armed-groups and traders are described. The Group documented armed activity at some mines covered by due diligence schemes as well as fraud and cross-border smuggling. Armed clashes between the police and armed individuals are reported. Reports from diggers, traders and authorities describe armed activity in specific mines. Eye-witnesses describe the distribution of machetes and rifles to diggers for use in clashes in Rubya, for example.

Details of mineral fraud are documented despite improved tagging procedures and the report notes areas of supply chains that may be contaminated. Named individual businessmen and gold traders are identified as providing food and finance to armed combatants digging for gold.

Earlier reports include: 


\title{
Midterm report of the Group of Experts on the Democratic Republic of the Congo [S/2020/1283]
}

United Nations Security Council, December 2020

https://reliefweb.int/report/democratic-republic-congo/midterm-report-group-experts-democraticrepublic-congo-s20201283

\author{
Final report of the Group of Experts on the Democratic Republic of the Congo \\ [S/2019/469] \\ United Nations Security Council, June 2019 \\ https://reliefweb.int/sites/reliefweb.int/files/resources/S_2019_469_E.pdf
}

\section{Policy and regulation}

Unintended consequences or ambivalent policy objectives? Conflict minerals and mining reform in the Democratic Republic of Congo

Diemel, J. A., \& Hilhorst, D. J. (2019). Development Policy Review, 37(4), 453-469.

https://onlinelibrary.wiley.com/doi/full/10.1111/dpr.12372

This discourse analysis looks at reform policy objectives aiming to break the linkages between mineral extraction and violent conflict. The study looked at four policy documents issued between 2010 and 2012: the UN Group of Experts report, the Dodd-Frank Wall Street Reform and Consumer Protection Act (article 1502), ${ }^{7}$ the OECD Due Diligence Guidance for Responsible Supply Chains of Minerals from Conflict-Affected and High-Risk Areas, and the International Conference on the Great Lake Region (ICGLR) Regional Certification Mechanism (RCM) Manual.

The authors find "much reform practice is geared towards conflict-free sourcing, and is far less appropriate when it comes to promoting peace" (p453) and that these two objectives may be out of alignment. Policies are often implemented in zones where there is little conflict and are narrow in scope. The policies tended to rely too heavily on the government and there was indifference to the impact of the reforms on poor miners. The authors question whether traceability is in place to clear the conscience of buyers rather than to improve the situation for the Congolese population.

\section{Exaggerating unintended effects? Competing narratives on the impact of conflict minerals regulation}

Koch, D. \& Kinsbergen, S. (2018). Resources Policy, 57, 255-263.

https://www.sciencedirect.com/science/article/pii/S0301420717302222

\footnotetext{
7 An outline of Dodd-Frank 1502 can be found here https://enoughproject.org/special-topics/progress-andchallenges-conflict-minerals-facts-dodd-frank-1502 (accessed 3/9/21)
} 
This article analyses the Dodd-Frank act (article 1502) which "obliges stock listed companies in the United States to declare which due diligence they exercised to prevent Tin, Tungsten, Tantalite and Gold (3TG) in their supply chain from contributing to conflict in the Great Lakes region of Africa" (p256). Authors find that when negative unintended effects were declining companies who stood to gain from deregulation were omitting this positive change from their narrative. Researchers and policy makers are cautioned in reproducing or using claims without critical assessment.

\section{Successful implementation of conflict mineral certification and due diligence schemes and the European Union's role: lessons learned for responsible mineral supply}

Eslave, N. (2018). Projekt Consult. STRADE. Funded by the Horizon 2020 Programme of the European Union Programme.

http://stradeproject.eu/fileadmin/user_upload/pdf/STRADE_Report_D4.19_Due_Diligence_Certifi cation.pdf

This report finds limited implementation of mine certification, traceability, or due diligence in mining practices in the DRC. Considerations around implementation identified by the report are:

- Whether the principal focus is on artisanal or small-scale mining

- Certification approach pass/fail or progressive

- Whether implementers are local government agencies or third-parties

- Data collection and dispersion methods.

"Due diligence and supply chain transparency mechanisms that issue certifications in the mid- to downstream fully depend on the successful implementation of standards in the upstream" (p2).

Institutional quality and enforcement tends to be lacking in the upstream. Standards implemented by third-parties fare better in areas of limited government capacity. However, third parties are more expensive and so less favoured by small operators. Downstream operators face implementation costs, lack of clarity regarding exact requirements, lack of cooperation from suppliers, and reporting.

Audit costs may be higher for artisanal mining regulation as the dynamism of the sector requires more regular audits. Standards that use minimum and incremental progress criteria together are suggested to be successful as operators can gradually improve their practice and large-scale operators are pushed towards full alignment with international best practice.

Strategic Dialogue on Sustainable Raw Materials for Europe (STRADE) recommendations include:

- Assessment of how standards have impacted the conditions they sought to change

- Set an example by encouraging responsible mineral sourcing via its public procurement rules either via regulatory demands or through preferential bid evaluation

- Adopt a methodology that allows Conflict-Affected High-Risk Areas (CAHRAs) to be identified at the sub-national level and to be adapted over short periods of time

- Fund supply chain research and development

- Undertake periodic assessment of standards 
- Consider the local social and cultural dynamics that underpin the activity, leading to the design of inadequate incentives for certification.

\section{Resource cursed or policy cursed? US regulation of conflict minerals and violence in the Congo}

Parker, D. P., \& Vadheim, B. (2017). Journal of the Association of Environmental and Resource Economists, 4(1), 1-49.

https://www.journals.uchicago.edu/doi/full/10.1086/689865

This report uses georeferenced before and after data to look at the impacts of the Dodd-Frank Act of 2010 section on conflict minerals. The research finds looting increased by $143 \%$ (from 2004 to 2012) and that battles were more likely in territories with unregulated gold since the legislation. The authors look at pathways from resource value shocks to conflict. Labour intensive, artisanal mining will produce opportunity cost effects lowering the net value of mineral endowment and increasing conflict.

An analytical framework looks at militia group choices and how different site values are affected by the legislation.

\section{Challenges for Global Supply Chain Sustainability: Evidence from Conflict Minerals Reports}

Kim, Y. H., \& Davis, G. F. (2016). Academy of Management Journal, 59(6), 1896-1916. https:/journals.aom.org/doi/abs/10.5465/amj.2015.0770

Investigation of corporation response to Section 1502 of the Dodd-Frank Act found that almost $80 \%$ (of 1,300 corporations in the study) were unable to determine the country of origin of materials and only $1 \%$ could certify themselves as conflict-free with certainty beyond reasonable doubt. Internationally diversified firms and those with more dispersed supply chains were less likely to declare their products conflict-free. Widespread outsourcing reduces capacity to account for the practices that yield products.

\section{An Unintended Legacy: The External Policy Responses of the USA and European Union to Conflict Minerals in Africa}

Addaney, M., \& Lubaale, E. C. (2021). An Unintended Legacy: The External Policy Responses of the USA and European Union to Conflict Minerals in Africa. Laws, 10(2), 50.

https://www.mdpi.com/2075-471X/10/2/50

In 2017 the European Union (EU) adopted regulations ${ }^{8}$ to stop the importation of conflict minerals in Europe and they come into force in 2021. This article analyses the regulations in light of Section 1052 of the US Dodd-Frank Act. Challenges identified with the implementation of the

\footnotetext{
8 The regulations are available here https://eur-lex.europa.eu/legalcontent/EN/TXT/PDF/?uri=CELEX:32017R0821\&from=EN (accessed on 12 May 2021)
} 
Dodd-Frank Act include the abandonment of minerals by several companies who were not prepared to take on the extra costs and due diligence which negatively affected incomes and livelihoods for civilians. Armed groups resorted to looting to make up for lost funding.

The authors suggest that the EU regulation is a weak normative framework for redressing conflict mineral issues. The targeting of importers mean that companies dealing with finished products will not be accountable. There is also a risk that importation shifts to companies based outside of the EU. Another weakness in the regulation is that small quantities are exempt. And there is concern over the scope of natural resources covered.

\section{Unintended Consequences of Sanctions for Human Rights: Conflict Minerals and Infant Mortality}

Parker, D. P., Foltz, J. D., \& Elsea, D. (2016). The Journal of Law and Economics, 59(4), 731-774. https://www.journals.uchicago.edu/doi/abs/10.1086/691793

This report estimates the effect of the Dodd-Frank Act, and its resultant reduction in mineral purchases, on infant mortality in Eastern DRC. The authors find the probability of infant deaths for children born before 2013 to have increased by $143 \%$. This is proposed to be connected to the reduction in mothers' consumption of infant health care goods and services.

\section{Conflict Minerals in the Corporate Supply Chain: Is Transparency the Solution to Human Rights Violations in the Tantalum, Tin, Tungsten and Gold Supply Chains? Härkönen, E. (2018). European Business Law Review, 29(5). \\ https://kluwerlawonline.com/journalarticle/European+Business+Law+Review/29.5/EULR2018027}

This article suggests ways in which the costs of transparency requirements for companies can be reduced. The author identifies slow speed of participation of actors in the supply chain as a hindrance to transparency. The report recognised legislation as only one component of a multilevel approach that is required to solve armed conflicts in resource rich countries.

\section{Further links}

A Swiss-Army Knife? A Critical Assessment of the Extractive Industries Transparency Initiative (EITI) in Ghana Andrews, N. (2016). Business and Society Review, 121(1), 59-83.

https://onlinelibrary.wiley.com/doi/abs/10.1111/basr.12081

The Impact of Dodd-Frank and Conflict Minerals Reforms on Eastern Congo's Conflict Bafilemba, F., Mueller, T., \& Lezhnev, S. (2014). The Enough Project.

https://enoughproject.org/files/Enough\%20Project\%20-\%20The\%20Impact\%20of\%20DoddFrank\%20and\%20Conflict\%20Minerals\%20Reforms\%20on\%20Eastern\%20Congo\%E2\%80\%99 s\%20Conflict\%2010June2014.pdf 
Not only a man's world: women's involvement in artisanal mining in eastern DRC Bashwira, M. R., Cuvelier, J., Hilhorst, D., \& Van der Haar, G. (2014). Resources Policy, 40, 109116.

https://www.sciencedirect.com/science/article/abs/pii/S030142071300113X

Governing natural resources for peace: Lessons from Liberia and Sierra Leone Beevers, M. D. (2015). Global Governance, 21, 227.

https://www.jstor.org/stable/24526163

Bandits or states? Armed groups' expropriation strategies and the economy: evidence from Eastern Congo

de la Sierra. R. S. (2014). Private Enterprise Development in Low-Income Countries (PEDL)

Research Note.

https://pedl.cepr.org/sites/default/files/Research\%20Note_Sanchez_de_la_Sierra.pdf

European draft Regulation on responsible mineral sourcing. What lessons can be learned from the Democratic Republic of Congo?

EurAc. (2014). Eurach Research.

https://www.brot-fuer-die-welt.de/fileadmin/mediapool/blogs/Online-Redaktion/eurac-position-

lessons-drc-conflict-minerals.pdf

Artisanal mining and conflict financing in eastern Democratic Republic of Congo (DRC); coping, conflict and shadow economy actors and the impact of the 'conflict minerals' campaign

Garrett, N. (2014). (Doctoral dissertation).

https://refubium.fu-berlin.de/handle/fub188/7960

Conflict minerals and supply chain due diligence: an exploratory study of multi-tier supply chains

Hofmann, H., Schleper, M. C., \& Blome, C. (2018). Journal of Business Ethics, 147(1), 115-141.

https://link.springer.com/article/10.1007/s10551-015-2963-z

Illegal gold mining and violence in Colombia

Idrobo, N., Mejía, D., \& Tribin, A. M. (2014). Peace Economics, Peace Science and Public

Policy, 20(1), 83-111.

https://www.degruyter.com/document/doi/10.1515/peps-2013-0053/html

Conflict Minerals Regulation: Mapping International Initiatives and Challenges Ahead Iglesias, J. C. (2014). Southern African Peace and Security Studies, 3(1), 45-59.

http://www.saccps.org/pdf/3-1/SAPSS\%203(1)\%20Castillo\%20lglesias.pdf

Social movement NGOs and the comprehensiveness of conflict mineral disclosures: evidence from global companies

Islam, M. A., \& van Staden, C. J. (2018). Accounting, Organizations and Society, 65, 1-19.

https://www.sciencedirect.com/science/article/abs/pii/S0361368217301149

Conflict minerals in electronic systems: An overview and critique of legal initiatives Jameson, N. J., Song, X., \& Pecht, M. (2016). Science and engineering ethics, 22(5), 1375-1389. https://link.springer.com/article/10.1007/s11948-015-9704-7 
"This mine has become our farmland": Critical perspectives on the coevolution of artisanal mining and conflict in the Democratic Republic of the Congo.

Kelly, J. T. (2014). Resources Policy, 40, 100-108.

https://www.sciencedirect.com/science/article/abs/pii/S0301420713001219

'Conflict Minerals' initiatives in DR Congo: Perceptions of local mining communities Matthysen, K., Montejano, A. Z., \& International Peace Information Service (Antwerp). (2013). Antwerp: International Peace Information Service.

https://reliefweb.int/sites/reliefweb.int/files/resources/20131112_HU.pdf 2013

The new EU conflict minerals regulation: Normative power in international relations? Partzsch, L. (2018). Global Policy, 9(4), 479-488.

https://onlinelibrary.wiley.com/doi/full/10.1111/1758-5899.12575

Fighting windmills in Eastern Congo? The ambiguous impact of the 'conflict minerals' movement

Radley, B., \& Vogel, C. (2015). The Extractive industries and society, 2(3), 406-410.

https://www.sciencedirect.com/science/article/abs/pii/S2214790X1500088X

Social assessment and management of conflict minerals: a systematic literature review Silva, S., \& Schaltegger, S. (2019). Sustainability Accounting, Management and Policy Journal. https://www.emerald.com/insight/content/doi/10.1108/SAMPJ-02-2018-0029/full/html

Why responsible sourcing of DRC minerals has major weak spots

Schouten, P. (2019). Why responsible sourcing of DRC minerals has major weak spots. Conflict Research Programme Blog.

https://blogs.Ise.ac.uk/crp/2019/09/19/why-responsible-sourcing-of-drc-minerals-has-major-weakspots/

Cost-Benefit Analysis and the Conflict Minerals Rule

Schwartz, J., \& Nelson, A. (2016). ADMiN. L. REv., 68, 287.

https://heinonline.org/HOL/LandingPage?handle=hein.journals/admin68\&div=14\&id=\&page=

The landscape of armed groups in Eastern Congo: fragmented, politicized networks Stearns, J., \& Vogel, C. (2017). Kivu security tracker, (December).

https://biblio.ugent.be/publication/8681206/file/8681208

The Role of Natural Resources in Disarmament, Demobilization and Reintegration. Addressing Risks and Seizing Opportunities

UNDP (2013). https://postconflict.unep.ch/publications/UNEP_UNDP_NRM_DDR.pdf

Conflict Minerals: Actions Needed to Assess Progress Addressing Armed Groups' Exploitation of Minerals

United States Government Accountability Office (2020).

https://www.gao.gov/assets/gao-20-595-highlights.pdf

Minerals and Conflict. A toolkit for intervention

USAID (2020).

https://rmportal.net/library/content/tools/conflict-assessment-and-management-

tools/conflict_minerals/at_download/file 
A miner's canary in eastern Congo: Formalisation of artisanal 3T mining and precarious livelihoods in South Kivu

Vogel, C., Musamba, J., \& Radley, B. (2018). The Extractive Industries and Society, 5(1), 73-80. https://www.sciencedirect.com/science/article/abs/pii/S2214790X16301241

Terr (it) or (ies) of peace? The Congolese mining frontier and the fight against "conflict minerals"

Vogel, C., \& Raeymaekers, T. (2016). Antipode, 48(4), 1102-1121.

https://onlinelibrary.wiley.com/doi/abs/10.1111/anti.12236

From 'conflict minerals' to peace? Reviewing mining reforms, gender, and state performance in eastern Democratic Republic of Congo

Wakenge, C. I., Nyenyezi, M. R. B., Bergh, S. I., \& Cuvelier, J. (2021). The Extractive Industries and Society, 100894.

https://www.sciencedirect.com/science/article/pii/S2214790X21000393

Responsible sourcing of metals: certification approaches for conflict minerals and conflict-free metals

Young, S. B. (2018). The International Journal of Life Cycle Assessment, 23(7), 1429-1447. https://link.springer.com/article/10.1007/s11367-015-0932-5

Jumping the chain: how downstream manufacturers engage with deep suppliers of conflict minerals

Young, S. B., Fernandes, S., \& Wood, M. O. (2019). Resources, 8(1), 26.

https://www.mdpi.com/2079-9276/8/1/26

\section{Acknowledgements}

We thank the following experts who voluntarily provided suggestions for relevant literature or other advice to the author to support the preparation of this report. The content of the report does not necessarily reflect the opinions of any of the experts consulted.

- Judith Verweijen, The University of Sheffield

- Lucy Williams, International Alert

- Peer Schouten, Danish Institute for International Studies

- Marco Jowell, FCDO

- Annette Juma, GIZ

\section{Suggested citation}

Bolton, L. (2021). Armed groups and mining. K4D Helpdesk Report. Brighton, UK: Institute of Development Studies. DOI 10.19088/K4D.2021.137

\section{About this report}

This report is based on six days of desk-based research. The K4D research helpdesk provides rapid syntheses of a selection of recent relevant literature and international expert thinking in response to specific questions relating to international development. For any enquiries, contact helpdesk@k4d.info. 
K4D services are provided by a consortium of leading organisations working in international development, led by the Institute of Development Studies (IDS), with Education Development Trust, Itad, University of Leeds Nuffield Centre for International Health and Development, Liverpool School of Tropical Medicine (LSTM), University of Birmingham International Development Department (IDD) and the University of Manchester Humanitarian and Conflict Response Institute (HCRI).

This report was prepared for the UK Government's Foreign, Commonwealth and Development Office (FCDO) and its partners in support of pro-poor programmes. Except where otherwise stated, it is licensed for non-commercial purposes under the terms of the Open Government License v3.0. K4D cannot be held responsible for errors, omissions or any consequences arising from the use of information contained in this report. Any views and opinions expressed do not necessarily reflect those of FCDO, K4D or any other contributing organisation.

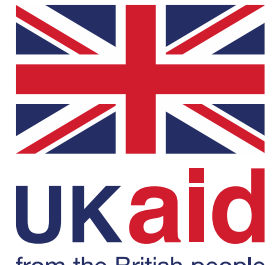

(C) Crown copyright 2021. 